M. B. Fedko, Cand. Sc. (Tech.), Assoc. Prof., orcid.org/0000-0003-4169-7425, I. O. Muzyka, Cand. Sc. (Tech.), orcid.org/0000-0002-9202-2973, S. V. Pysmennyi, Cand. Sc. (Tech.), Assoc. Prof., orcid.org/0000-0001-5384-6972, O. V. Kalinichenko, Cand. Sc. (Econ.), Assoc. Prof., orcid.org/0000-0002-9138-9271

\title{
DETERMINATION OF DRILLING AND BLASTING PARAMETERS CONSIDERING THE STRESS-STRAIN STATE OF ROCK ORES
}

Purpose. Enhancing methods for determining parameters of drilling and blasting operations considering the stress-strain state of rocks.

Methodology. Dependency of the inclined exposure dip on the stress-strain state of rocks to be caved is determined by the analytical research technique and mathematical modeling applying the finite element method.

Findings. The work offers methods for determining the energy intensity factor for breaking ores onto the inclined exposure which considers the exposure dip while correcting drilling and blasting parameters. There are also offered calculated numerical limits for the above factor.

Originality. The scientific novelty consists in determining numerical values of the energy intensity factor for breaking the rock massif considering its stress-strain state when caving onto an inclined exposure (compensation area) taking into account its dip. The work suggests limiting the range of obtained numerical values of the factor when breaking the massif onto any type of exposures.

Practical value. Drilling and blasting parameters can be corrected depending on changes of the ore massif stressstrain state when caving it onto any type of exposures (horizontal, vertical or inclined). The dedicated computer program created enables immediate acquisition of basic drilling and blasting parameters for particular conditions and analysis of predicted values of fragmentation of the massif to be caved.

Keywords: drilling and blasting parameters, stress-strain state of the massif

Introduction. The current crisis phenomena add urgency to the issue of additional reserves of decreasing ore mining costs and those of underground mining in particular. Due to high prices for explosives and blasting means, drilling and blasting operations make a considerable part of mining costs. Consequently, increase in efficiency of this important production process influencing the further operation indices (muck drawing and transportation) becomes topical.

Analysis of the recent research and publications. Basic parameters of drilling and blasting (DB) at longhole stoping, which is dominant in underground iron ore mining, are determined by a wide range of various methods described in scientific and technical literature. For instance, theoretical (so called "benchmark") explosive consumption underlies the mining methods in [1]. The statistical data resulted from analysis of DB parameters in underground mines is taken as a basis in [2,3] and determines these parameters for a round of parallelcontiguous boreholes. However, the mentioned techniques do not consider the influence of the depth of operations and the stress-strain state (SSS) of rocks caused by it.

One of the widely used techniques was developed by prof. Yu. P. Kaplenko. It has been approved as the industry standard for iron ore underground mines of Kryvbas and Zaporizhzhia Iron Ore Integrated Plant and is used by students for preparing their course and graduation

(C) Fedko M. B., Muzyka I. O., Pysmennyi S. V., Kalinichenko O.V., 2019 papers [4]. The technique is based on the so called rock blastability index $C_{0}$, which considers all basic factors influencing breaking efficiency. In practice its simplified version, which considers the rock hardness ratio, rock heterogeneity, a borehole diameter, the explosive force and charge density, is applied. In most cases the calculated parameters of DB completely meet the industry's requirements as the methods are based on a great amount of industrial research and undergone significant testing [5]. However, the full version of the technique enables considering the stress-strain state of rocks and, consequently, adjusts basic parameters of explosives. Though the technique is adequately treated in technical literature $[3,6]$, it is not widely applied in practice. From our point of view, the main reasons for this include considerably more difficult calculations and lack of motivation of technical and engineering employees to apply these cumbersome and complicated methods.

According to the technique, when designing drilling and blasting operations, the stress-strain state of rocks is determined using the energy intensity factor for breaking rocks $k_{\sigma}$ equal to the ratio of specific consumption of explosives considering the impact of mining depths and the stoping area sizes $q_{\sigma}$ to specific consumption of explosives determined on according to rock hardness $q_{f}$.

Unsolved aspects of the problem. The main disadvantage of the above mentioned technique is as follows. Firstly, it only allows determining the numeric value $k_{\sigma}$ when breaking ore onto horizontal or vertical exposures, but in Kryvbas underground mines the inclined type of 
exposures (compensation areas) is becoming more frequent in both sublevel stoping and sublevel caving. Secondly, it does not contain any limitations that can lead to inaccurate results.

The investigation is aimed at enhancement of the methods for determining DB parameters considering the stress-strain state of rocks in terms of possible adjustment of explosives parameters when caving the rocks onto the inclined exposure (compensation area), and setting certain limits to disable inaccurate results.

Presentation of the main research. The numerical value of the factor $k_{\sigma}$ is determined from the expressions:

- when breaking ore onto the horizontal exposure (compensation area)

$$
K_{\sigma}=1.5+\frac{1}{q_{f}} \cdot\left(0.4 \cdot e^{-\frac{B}{W_{f}}}-\frac{S_{v} \cdot \sqrt{H}}{f \cdot 10^{4}}\right)
$$

- when breaking ore onto the vertical cutoff stope (compensation room)

$$
K_{\sigma}=1.5+\frac{1}{q_{f}} \cdot\left[0.4 \cdot e^{-\frac{B}{W_{f}}}-\frac{S_{h} \cdot \sqrt{\frac{H \cdot \mu}{1-\mu}}}{f \cdot 10^{4}}\right],
$$

where $q_{f}$ is specific consumption of explosives according to rock hardness, $\mathrm{kg} / \mathrm{t} ; B$ is the stope width, $\mathrm{m} ; W_{f}$ is the line of the least resistance for the given rock hardness $f$, $\mathrm{m} ; S_{h}, S_{v}$, are the areas of the horizontal or vertical stopes respectively, $\mathrm{m}^{2} ; H$ is the depth of mining operations, $m ; \mu$ is Poisson's ratio, unit fractions.

When numerical value of the energy intensity factor for breaking ores $k_{\sigma}$ is less than 1 , this testifies to the fact that the rocks are in the zone of lower or tension stresses which weaken the massif. This allows increasing the parameters of the spacing pattern without muck quality losses while decreasing the number of boreholes (and their reduced general length), explosives and means of blasting. Accordingly, productivity increases and costs of the process decreases. $k_{\sigma}$ greater than 1 testifies to prevalent compressive stresses which complicate rock fragmentation as, apart from the compressive stresses, natural forces characterized by these rocks' hardness ratio should also be handled. If the mentioned factor is not considered, under the influence of increased compressive stresses the fragmented ore quality decreases due to increased oversize yield.

Considering the stress-strain state of rocks, the blastability index, the least resistance line value and specific consumption of explosives for breaking are determined through the formulas

$$
\begin{aligned}
& C_{\sigma}=\frac{C_{0}}{\sqrt[3]{K_{\sigma}}} ; \\
& W_{\sigma}=\frac{W_{0}}{\sqrt[3]{K_{\sigma}}} ; \\
& q_{\sigma}=q_{f} \cdot K_{\sigma} .
\end{aligned}
$$

We have investigated changes of the stress-strain state of rocks and enclosing rocks with various types of exposures at sublevel stoping when breaking the ore onto horizontal, vertical and inclined compensation areas. The investigation was conducted through mathematical modeling applying the finite elements method in Ansis 16.2. Exposure (inclined crowns and roofs of inclined compensation rooms) dips made 20 to $70 \mathrm{de}$ grees.

Fig. 1 exemplifies modeling of the stress-strain state of rocks around horizontal, vertical and inclines compensation rooms of the same volume and in the same conditions (mining depth - $1350 \mathrm{~m}$, Protodyakonov hardness of rocks -5 points).

The figures demonstrate that with the horizontal exposure (Fig. 1) increased compressive stress zones are concentrated in the upper corners of the stope and occur in very small areas. The major part of the massif is influenced by decreased and tension stresses. Rocks weakened by decreased and tension stresses are similar to rocks of less hardness. This is considered, particularly, by applying the factor $k_{\sigma}^{h}$. With vertical exposures (Fig. 2), increased compressive stress zones are observed in the lower and upper corners of the stope. The sizes and absolute values of these zones are similar to those in corner areas of the stope with a vertical exposure. In the central part of the vertical exposure there are no tension stresses (at least, at the specified depth and sizes of the exposure); but there occurs a zone of decreased compressive stresses the level of which grows inward the massif. Such pattern of stress field development completely meets the classical idea of stress field formation around stopes of this shape and is in good agreement with other authors' investigations [6, 7], which proves accuracy of the obtained modeling results.

Absolute values of the stresses in the massif and sizes of zones where they develop (with both horizontal and vertical exposures) will depend on physical and mechanical properties of rocks, mining depth and geometrical sizes of such exposures. With decrease in rock

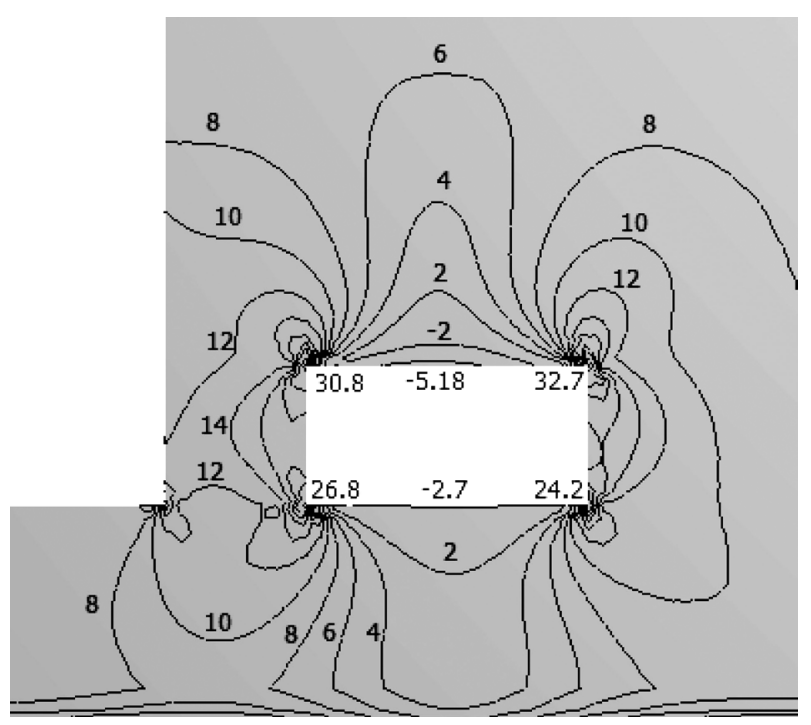

Fig. 1. Distribution of the principal stresses field (MPa) round the horizontal compensation room 


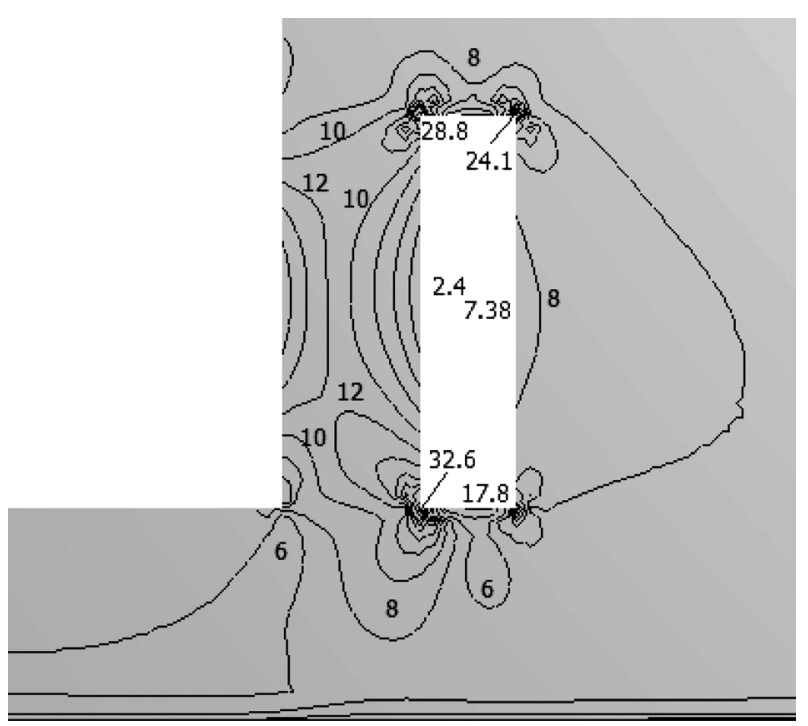

Fig. 2. Distribution of the principal stresses field (MPa) round the vertical compensation room

hardness, increase in rock pressure, which depends directly on the mining depth, and increase in exposure sizes in the stope roof and walls, there occur disturbances in the form of rock falls $[8,9]$. However, in similar conditions vertical exposures are more stable than horizontal ones and conditions of breaking in the rock massif to be caved onto horizontal exposures will always be more favorable. This is proved by calculations of $k_{\sigma}^{v}$ and $k_{\sigma}^{h}$ according to $[2,10]$.

With inclined exposures (Fig. 3), the rocks over the room are also influenced by decreased and tension stresses, but their level is significantly less than in case of the horizontal exposure. So, in similar conditions inclined exposures are more stable than horizontal ones, but they are less stable than vertical exposures. This dependency is in complete agreement with the results presented in [11].

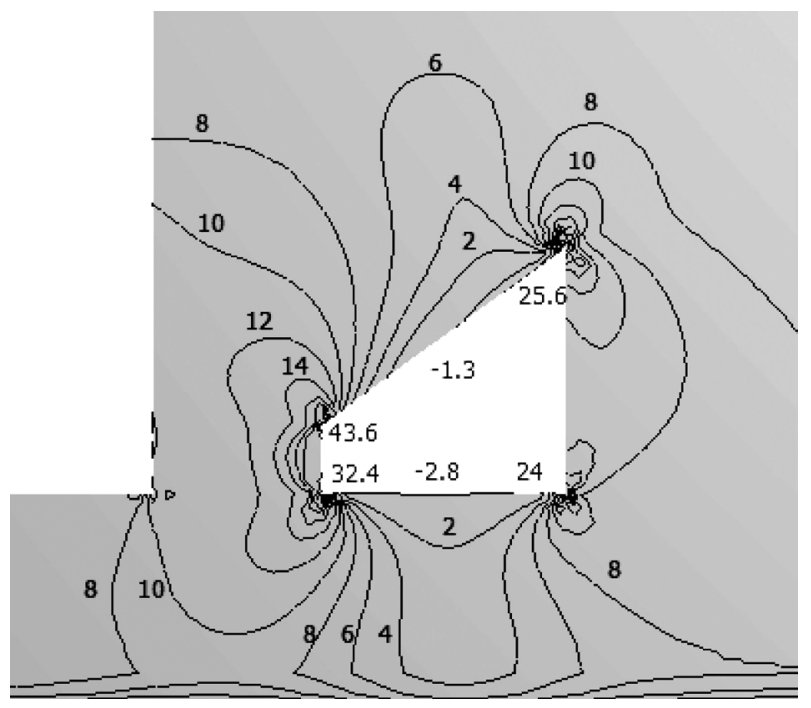

Fig. 3. Distribution of the principal stresses field (MPa) round the inclined compensation room with the inclined exposure dip of $40^{\circ}$
The value of inclined exposure stability change is directly connected with its dip. With small dips of inclined exposures $\left(20-30^{\circ}\right)$ the level of stresses in the massif and their stability vary little from those in horizontal crowns or horizontal compensation rooms. At greater dips (especially $60^{\circ}$ and more) stability of inclined exposures fast reaches that of vertical exposures.

Analysis of the obtained data enables determining the value of $k_{\sigma}$ at caving onto the inclined exposure (compensation area) from the expression

$$
k_{\sigma}^{n}=k_{\sigma}^{h}+\left(k_{\sigma}^{v}-k_{\sigma}^{h}\right) \cdot \operatorname{tg}^{2} \Theta / 2,
$$

where $k_{\sigma}^{v}, k_{\sigma}^{h}$ are values of $k_{\sigma}$ when breaking onto the vertical and horizontal exposures (compensation areas) respectively; $\Theta$ is the dip of the inclined exposure, degrees.

Analysis of this expression shows that at $\Theta=0^{\circ}$ and $\Theta=90^{\circ}$ (i. e. at horizontal and vertical exposures) $k_{\sigma}^{n}$ becomes equal to $k_{\sigma}^{h}$ and $k_{\sigma}^{v}$ respectively; the greater the inclined exposure $\operatorname{dip} \Theta$ is (i.e. when its stability increases due to increase of the zone of compressive stresses impact and their absolute values), the greater the factor $k_{\sigma}^{n}$ becomes.

Fig. 4 presents changes in numerical values $k_{\sigma}^{n}$ depending on the inclined exposure dip $\Theta$ in concrete conditions, namely: with Protodyakonov hardness of rocks $f=6$ points; exposure area $S=400 \mathrm{~m}^{2}$; depth of mining $H=1200 \mathrm{~m}$ and Poisson's ratio $\mu=0.3$.

As is seen, at the inclined exposure dips up to $20-30^{\circ}$ there is no great difference between values $k_{\sigma}^{h}$ and $k_{\sigma}^{n}$, significant increase in $k_{\sigma}^{n}$ is observed at dips from $40-50^{\circ}$ and greater. Such behavior of rocks is logical and confirmed by a number of experimental investigations when modeling the stress-strain state of rocks at previous stages of studying geomechanical processes [12, 13] and visual observations at Kryvbas underground mines. The similar dependency of inclined exposure stability increase is presented in [14] and this can also confirm accuracy of the obtained data.

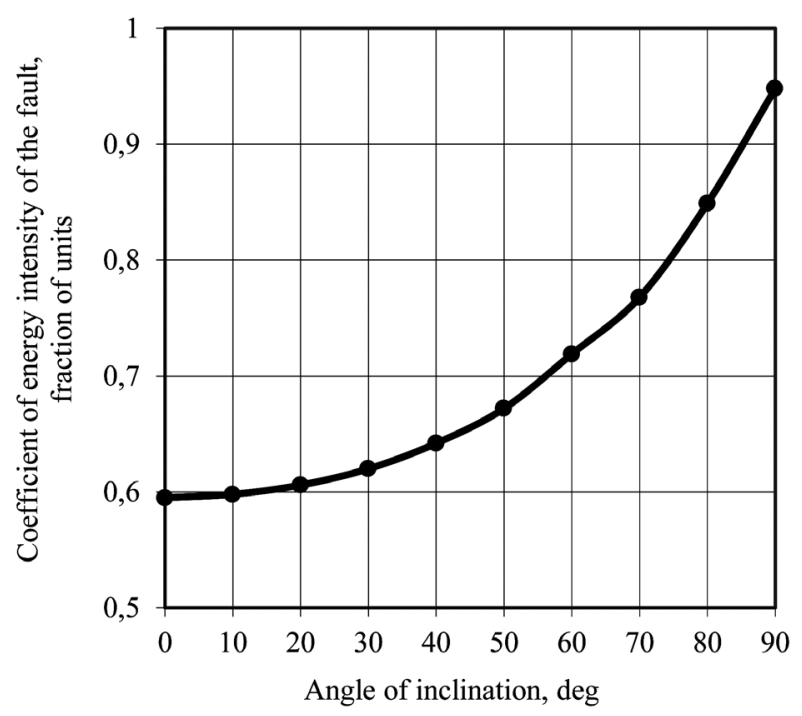

Fig. 4. Dependency of the energy intensity coefficient for breaking rocks $k_{\sigma}^{n}$ on the inclined exposure dip $\Theta$ 
As for limitations to the above mentioned technique, we suppose that with values of $k_{\sigma}$ less than $0.4-0.5$ the state of exposures and the marginal part of the massif will be critical due to development of the tension stress zone in it that may result in high probability of falls. In such cases stability of a particular exposure should be additionally checked according [15].

Indices of quality of fragmented ore in concrete conditions with the designed parameters of drilling and blasting (a diameter of an average blasted ore lump, oversize yield) can be determined according to the above mentioned technique by prof. Yu. P. Kaplenko. However, these calculations are laborious due to cumbersome empirical equations describing the dependencies. To make the calculations more convenient, we have developed a dedicated computer program enabling rapid generation of data on basic drilling and blasting parameters considering both hardness of rocks and their stressstrain state.

Conclusions. The enhanced methods developed by prof. Yu.P. Kaplenko that consider the influence of the stress-strain state of rocks on conditions of their breaking can be used for calculating drilling and blasting parameters for any types of exposures (compensation areas). The calculations can be performed very quickly due to a dedicated computer program enabling preliminary analysis of basic indices of ore breaking (specific consumption of explosives, ore yield from $1 \mathrm{~m}$ of a borehole, a diameter of an average muck lump, oversize yield). Correlation of the obtained data in some cases with stability of exposures and rocks to be caved will enable avoidance of inaccurate results.

\section{References.}

1. Khomenko, O., Kononenko, M. and Myronova, I., 2013. Blasting works technology to decrease an emission of harmful matters into the mine atmosphere. In: Annual Scientific-Technical Colletion - Mining of Mineral Deposits, pp. 231-235.

2. Fedko, M. B., Kolosov, V.A., Pismennyi, S. V. and Kalinichenko, Ye. V., 2014. Economic aspects of changeover to TNT-free explosives for the purposes of ore underground mining in Kryvyi Rih basin. Naukovyi Visnyk Natsionalnoho Hirnychoho Universytetu, 4, pp. 79-84.

3. Stupnik, N. and Kalinichenko, V., 2012. Parameters of shear zone and methods of their conditions control at underground mining of steep-dipping iron ore deposits in Kryvyi Rig basin. In: Geomechanical Processes During Underground Mining - Proceedings of the School of Underground Mining, pp. 15-19.

4. Khomenko, O. and Maltsev, D., 2013. Laboratory research of influence of face area dimensions on the state of uranium ore layers being broken. Naukovyi Visnyk Natsionalnoho Hirnychoho Universytetu, 2, pp. 31-37.

5. Rymarchuk, B. I., Shepel, O. L. and Khudyk, M. V., 2017. Expediency of application of the vertical concentrated charges to decrease losses of ore on a lying wall of deposits. Naukovyi Visnyk Natsionalnoho Hirnychoho Universytetu, 3 pp. 32-37.

6. Khomenko, O., Kononenko, M. and Myronova, I., 2017. Ecological and technological aspects of iron-ore underground mining. Mining of Mineral Deposits, 2(11), pp. 59-67.

7. Kononenko, M.N., Petlevany, M.V. and Zubko, S.A., 2015. Formation of stress fields in a bookmarking array around the chambers with increasing depth of mining operations. In: Mining of mineral deposits: annual scientific-technical collection, pp. 207-215.

8. Stupnik, N., Kalinichenko, V. and Pismennyi, S., 2013. Pillars sizing at magnetite quartzites room-work. In: Annual Scientific-Technical Colletion - Mining of Mineral Deposits, pp. 11-15.

9. Stupnik, N., Kalinichenko, V., Kolosov, V., Pismennyi, S. and Shepel, A., 2014. Modeling of stopes in soft ores during ore mining theme. Metallurgical and mining industry, 3, pp. 32-36.

10. Plevako, V., Potapov, V., Kycenko, V., Lebedynecj, I. and Pedorych, I., 2016. Analytical study of the bending of isotropic plates, inhomogeneous in thickness. Eastern-European Journal of Enterprise Technologies, 4(7(82)), pp. 10-16.

11. Stupnik, N. and Kalinichenko, V., 2013. Magnetite quartzite mining is the future of Kryvyi Rig iron ore basin. In: Annual Scientific-Technical Colletion - Mining of Mineral Deposits, pp. 49-52.

12. Morkun, V., Morkun, N. and Tron, V., 2015. Formalization and frequency analysis of robust control of ore beneficiation technological processes under parametric uncertainty. Metallurgical and Mining Industry, 5, pp. 7-11.

13. Kononenko, M., Khomenko, O., Sudakov, A., Drobot, S. and Lkhagva, Ts., 2016. Numerical modelling of massif zonal structuring around underground working. Mining of Mineral Deposits, 12(3), pp. 101-106.

14. Morkun, V., Morkun, N. and Pikilnyak, A., 2014. Simulation of high-energy ultrasound propagation in heterogeneous medium using k-space method. Metallurgical and Mining Industry, 3, pp. 23-27.

15. Stupnik, N. I., Fedko, M.B., Pismennyi, S. V. and Kolosov, V.A., 2014. Development of recommendations for choosing excavation support types and junctions for uranium mines of state-owned enterprise skhidHZK. Naukovyi Visnyk Natsionalnoho Hirnychoho Universytetu, 5, pp. 21-25.

\section{Визначення параметрів буропідривних робіт з урахуванням напружено-деформованого стану рудного масиву}

\section{М. Б. Федько, І. О. Музика, С. В. Письменний, О. В. Калініченко}

Державний вищий навчальний заклад „Криворізький національний університет“, м. Кривий Ріг, Україна, e-mail:prrkk@ukr.net

Мета. Удосконалення методики визначення параметрів буропідривних робіт з урахуванням напружено-деформованого стану масиву гірських порід.

Методика. Із застосуванням аналітичного методу досліджень та шляхом математичного моделювання із застосуванням методу кінцевих елементів 
визначена залежність впливу кута нахилу похилого оголення на напружено-деформований стан масиву, що підлягає обваленню.

Результати. Запропонована методика визначення коефіцієнта енергоємності відбійки гірських порід при обваленні масиву на похиле оголення, що дає можливість ураховувати кут його нахилу. Запропоновані обмеження стосовно розрахованих чисельних значень вищезазначеного коефіцієнта.

Наукова новизна. Наукова новизна полягає у можливості визначення чисельних значень коефіцієнта енергоємності відбійки гірського масиву, що враховує його напружено-деформований стан при обваленні на похиле оголення (компенсаційний простір) з урахуванням кута його нахилу. Запропоновано обмежувати діапазон отриманих чисельних значень даного коефіцієнта при відбійці масиву на будь-який тип оголень.

Практична значимість. Можливість коригування параметрів буро-підривних робіт у залежності від змінення напружено-деформованого стану рудного масиву при його обваленні на будь-який тип оголення (горизонтальне, вертикальне або похиле). Створена спеціалізована комп'ютерна програма, що дозволяє оперативно отримувати значення основних параметрів буро-підривних робіт для конкретних умов та аналізувати прогнозні значення якості подрібнення масиву, що підлягає обваленню.

Ключові слова: параметри буро-підривних робіт, напружено-деформований стан масиву

\section{Определение параметров буровзрывных работ с учетом напряженно- деформированного состояния рудного массива}

\section{М. Б. Федько, И. О. Музыка, С. В. Письменный, Е. В. Калиниченко}

Государственное высшее учебное заведение „Криворожский национальный университет“, г. Кривой Рог, Украина, e-mail: prrkk@ukr.net

Цель. Совершенствование методики определения параметров буровзрывных работ с учетом на- пряженно-деформированного состояния массива горных пород.

Методика. С использованием аналитического метода исследований и путем математического моделирования методом конечных элементов определена зависимость влияния угла наклона наклонного обнажения на напряженно-деформированное состояние массива, подлежащего обрушению.

Результаты. Предложена методика определения коэффициента энергоемкости отбойки горных пород при обрушении массива на наклонное обнажение, которая дает возможность адекватно учитывать угол наклона обнажения при корректировке параметров буровзрывных работ. Предложены ограничения по расчету численных значений коэффициента энергоемкости отбойки.

Научная новизна. Научная новизна заключается в возможности определения численных значений коэффициента энергоемкости отбойки горного массива, учитывающего его напряженно-деформированное состояние при обрушении на наклонное обнажение (компенсационное пространство) с учетом угла его наклона. Предложено ограничивать диапазон полученных численных значений данного коэффициента при отбойке массива на любой тип обнажений.

Практическая значимость. Возможность корректировки параметров буровзрывных работ в зависимости от изменения напряженно-деформированного состояния рудного массива при его обрушении на любой тип обнажения (горизонтальное, вертикальное или наклонное). Создана специализированная компьютерная программа, которая позволяет оперативно получать значения основных параметров буровзрывных работ для конкретных условий и анализировать прогнозные значения качества дробления массива, подлежащего обрушению.

Ключевые слова: параметры буровзрывных работ, напряженно-деформированное состояние массива

Рекомендовано до публікації докт. техн. наук Н.Ю. Швагером. Дата надходження рукопису 04.10.17. 